\title{
Era of Covid-19 Pandemic: Yoga contemplation and medical mystery
}

\author{
Prem Prakash Singh ${ }^{1}, \odot$ Vikas Chaurasia $^{2}$
}

${ }^{1}$ Depatment of Physical Education, S.V.N P.G. College, RML Avadh University, Ayodhya, India. ${ }^{2}$ Department of Computer Applications, VBS Purvanchal University, Jaunpur, India.

\begin{abstract}
Yoga is a complete science, a complete lifestyle, a complete medical practice and a complete spiritual education. The secret of the popularity of yoga is that it has never distinction from the narrowness of gender, caste, class, community, region and language. Any seeker, thinker, recluse, practitioner, brahmachari, householder can get benefited by attaining the same. It has proved useful not only in the creation and upliftment of the individual but also in the all-round development of the family, society, nation and the world. Yoga is the solution to the stress, disturbance, terrorism, lack and ignorance of modern human society. Yoga is a wonderful technique to bring man on the paved path of positive thinking which was invented by the intelligent sages of India, millions of years ago. Maharhi Patanjali performed it in the form of Ashtanga Yoga, disciplined, edited and executed. A healthy person and a happy society can only be created by going in the condition of yoga. Yoga is not only the discipline of ascetics, recluse and yogis who live in cave, but it is also very much needed for the general householder. It is a matter of surprise that we are ready to exploit our financial, physical and mental by falling into a two-hundred-year-old allopathic medical system. For millions of years, we remain indifferent to old yoga, remain ignorant, which is not only authentic but also teaches free treatment.
\end{abstract}

Keywords. Allopathic, Ashtanga yoga, brahmachari, spiritual education, stress, yoga.

\section{Introduction}

Yoga is obtained from Sanskrit word yuj, which means to aggravate, connect or connect together (Jyotsna et al., 2014). Its standard is to integrate all parts of the body with the soul and soul to achieve the ultimate satisfaction of a healthy lifestyle. Yoga is an ancient custom of stable life, which combines the body and deep control means that connect the body and the brain. It started in India 5,000 years ago. The earliest record of yoga was the Indian sage Patanjali, who lived about 2,000 or 2,500 years ago (Mehrotra et al., 2017). Over the centuries, many yoga schools have been developed, but they all follow the standards described by Patanjali.Patanjali's composing characterized an Ashtanga or "EightLimbed" Yoga in Yoga Sutras. They are:

1. Yama (The five abstentions): a) Ahimsa (Lochtefeld et al., 2003) (Non-viciousness, nonhurting other living beings), b) Satya (Dhand et al., 2002) (honesty, non-falsehood), c) Asteya (Gulati et al., 2008) (non-stealing), d) Brahmacharya (Gulati et al., 2008) (abstinence, loyalty to one's partner), e) Aparigraha (Dhand et al., 2002) (non-insatiability, nonpossessiveness).

2. Niyama (The five "observances"): a) Sauca (Sharma \& Sharma, 1996) (virtue, clearness of psyche, discourse and body), b) Santosha (Tummers et al., 2009) (happiness, acknowledgment of others and of one's circumstances), c) Tapas (Kaelber et al., 1976) (tenacious contemplation, persistence, austerity), d) Svadhyaya (Bhagwat et al., 2008) (investigation of self, self-reflection, investigation of Vedas), e) Ishvara-Pranidhana (Tummers et al., 2009) (thought of God/Supreme Being/True Self) 
3. Asana: Literally signifies "seat", and in Patanjali's Sutras alludes to the situated position utilized for reflection.

4. Pranayama ("Breath works out"): Prana, breath, "ayama", to "stretch, expand, limit, stop".

5. Pratyahara ("Abstraction"): Withdrawal of the sense organs from outside articles.

6. Dharana ("Concentration"): Fixing the consideration on a solitary item.

7. Dhyana ("Meditation"): Intense examination of the idea of the object of reflection.

8. Samadhi ("Liberation"): blending cognizance with the object of contemplation.

As per present day researchers, everything known to mankind is only an indication of a similar quantum atmosphere. One who encounters this unity of presence is supposed to be in yoga, and is named as a yogi, having achieved a condition of opportunity alluded to as mukti, nirvana or moksha. Along these lines the point of Yoga is Selfacknowledgment, to beat a wide range of sufferings prompting 'the condition of freedom' i.e. Moksha or 'opportunity' i.e. Kaivalya. Living with opportunity in varying backgrounds, wellbeing and amicability will be the primary goals of Yoga practice."Yoga" likewise alludes to an internal science including an assortment of strategies through which people can understand this association and accomplish dominance over their predetermination (Basavaraddi et al., 2015).Yoga is additionally ordinarily comprehended as a treatment or exercise framework for wellbeing and wellness. While physical and psychological wellnesses are characteristic results of yoga the objective of yoga is progressively sweeping. Yoga is tied in with orchestrating oneself with the universe. It is the innovation of adjusting singular geometry to the inestimable to accomplish the most elevated level of discernment and agreement.
Yoga has an important place in modern medical practice.Current medication has gained colossal ground in controlling transmittable illnesses over the previous century, with the end goal that it is presently the non-transferable sicknesses (NCDs) that have arrived at pestilence extents and cause most of passing around the world. The World Health Organization (WHO) assesses that $80 \%$ of NCD passing are because of four fundamental ailment types: cardiovascular malady, malignant growth, diabetes, and respiratory sicknesses (Khalsa et al., 2016). Shockingly, way of life is the major causative factor in NCDs, including tobacco use, stationary way of life, absence of ordinary exercise, undesirable eating regimens and incessant psychosocial stress (Khalsa et al., 2016, Hunter et al., 2013). Incessant aggravation and stress is a typical factor of a considerable lot of the NCDs, and a region where yoga has been seen as very helpful.yoga and care based practices can emphatically affect the body from various perspectives, including assisting with controlling blood glucose levels and keeping the cardiovascular framework sound. It additionally has been appeared to have significant mental advantages, as the act of yoga can assist with expanding readiness and positive emotions, and reduction negative sentiments of forcefulness, sorrow and tension (Miller et al., 1995; Yadav et al., 2015; Klainin et al., 2015; Amaranath et al., 2016; DeBruin et al., 2017; Danhauer et al., 2017). Some social insurance suppliers are reacting to these positive discoveries - just as the developing patient interest for an elective way to deal with health that is normal, low-tech, moderately reasonable and for the most part protected-by joining clinical yoga into their practices.

In the time of covid-19 pandemic, a solid invulnerable framework is essential for individuals as they are fighting against to a plenty of viruses. Invulnerability is the condition of having adequate organic resistances to maintain a strategic distance from contamination, malady, or other undesirable natural attack. It is the ability of the body to oppose hurtful microorganisms from entering it. 
Insusceptibility includes both explicit and vague segments. The vague segments act either as hindrances or as eliminators of wide scope of pathogens regardless of antigenic particularity. Different parts of the resistant framework adjust to each new infection experienced and can create pathogen-explicit invulnerability. Inborn invulnerability or vague insusceptibility is the normal protections with which an individual is conceived. It gives protections through a few physical, substance and cell approaches (Immunity, 2013).

\section{Yoga Contemplation}

Sound life can be considered as a result of rehearsing yogic strategies since it has been seen that Yoga specialists are genuinely and intellectually more advantageous and have preferred adapting aptitudes to stressors over the typical populace. Information on modest, viable and effectively administrable yogic methods by wellbeing experts will go far in helping us accomplish the objective of the World Health Organization to give "physical, mental, profound and social wellbeing" for all areas of human culture.

Apparently formal contemplation practice can change both cerebrum structure and capacity (Davidson et al., 2008). It has been discovered that individuals who accomplish more contemplation practice grow progressively vigorous mind structures in specific territories. Various examinations have demonstrated that yogic practices, for example, careful contemplation can increment both cortical thickness and dark issue, especially in zones controlling enthusiastic guideline and official working. These locales eminently incorporate the insula, the ventromedial pre-frontal cortex and foremost cingulate cortex (ACC) (Davidson et al., 2003; 2008). The insula is engaged with proprioception, mindfulness and passionate guideline. The ventromedial PFC is the mind's inside for official working, including arranging, critical thinking and enthusiastic guideline. The ACC is the self-administrative procedure place, enabling one to screen consideration clashes and take into consideration progressively intellectual adaptability (Ricard et al., 2014; Hernández et al., 2016; Deepeshwar et al., 2015; Villemure et al., 2015).

We can say that the eastern psyche body procedures influence each cell of the human body. They achieve better neuro-effector correspondence, improve quality, and upgrade ideal working of all organ-frameworks while expanding obstruction against stress and maladies with resultant serenity, balance, uplifting disposition and poise.

\section{How Yoga Can Effectively Treat Diseases?}

The cutting edge clinical framework has supplanted practically all the customary frameworks of medication in various pieces of this globe in light of its judicious premise. It has substantiated itself best in sparing man from the lethal hands of infectious and infectious maladies. Be that as it may, quickly expanding frequency of stress related afflictions is representing an extraordinary test to the advanced clinical framework. It is here that Yoga seems to make a fundamental commitment to the cutting edge clinical framework.

The for the most part practiced Yoga Sadhanas Practices are: Yama, Niyama, Asana, Pranayama, Pratyahara, Dharana, Dhyana Meditation, Samadhi or Samyama, Bandhas and Mudras, Shat-karmas, Yukta-ahara, Yukta karma, Mantra japa, etc. Yama's are constraints and Niyama's are observances. These are seen as pre-requisits for the Yoga Sadhanas (Practices). Asanas, fit for accomplishing adequacy of body and cerebrum ' kuryat-dab asanamsthairyam', involves in grasping distinctive body (psycho-physical) plans, offering ability to keep up a body position (a consistent awareness of one's assistant nearness) for an amazing length and time allotment as well.

The underlying driver of Stress actuated infirmities is the awkwardness at the ManomayaKosa. An enhanced preference at the 
manomaya kosa brings about distressful enthusiastic floods called 'Aadhi'. The way of life gets upset in light of long standing uncontrolled floods of upsetting responses like exceptional want (Kama), outrage (Krodha), dread (Bhaya), envy (Matsarya) and so forth., These disturbances cause rough vacillations in the progression of prana in the 'nadis' which are supposed to be the channels disseminated everywhere throughout the body through their stretching framework. Every single cell in the body, the segments of annamayakosa, requires right quantity of its pranic vitality to carry on its biochemical procedures in an effective manner. The model is that of continuous force gracefully important for each electrical contraption in right amounts. Similarly as these types of gear would fall flat if there is any anomaly in the force flexibly, human organ frameworks neglect to work on the off chance that they don't get the correct quantum of prana. In this way the aggravations in the Manomayakosa permeate into physical body (AnnamayaKosa) through upset prana streams. Subsequently the administration of these pressure incited afflictions should address lopsided characteristics at all these levels (physical, prana and brain) and help the patient build up himself in his Vijnanamaya and AnandamayaKosa which is the condition of opportunity from disease. Henceforth Yoga procedures are offered at all these levels, to address the lopsided characteristics through a lot of yoga rehearses which we have named as integrated methodology of yoga treatment (IAYT).

\section{Stress Management}

The expanding mindfulness that a considerable lot of the normal mental and psychosomatic issues have worry as the fundamental basic factor has prompted numerous investigations attempting to apply strategies of stress the executives in these sicknesses with empowering results. 'Yoga', which is an experiential science gives a methodical technique its firm roots in an all-encompassing way of thinking which is in complete concordance with nature. This science is the branch of thousands of long stretches of inside research by Indian sages. It is settled that pressure debilitates our resistant framework. Logical research as of late has indicated that the physiological, mental and biochemical impacts of yoga are of an enemy of stress nature. A lion's share of studies have portrayed useful impacts of yoga intercessions in worry with an Agency for Healthcare Research and Quality (AHRQ) report expressing that "Yoga diminished stress."(Ospina et al., 2007) Reductions in saw pressure following yoga are accounted for to be as viable as treatments, for example, unwinding, subjective conduct treatment and move treatment.

\section{Back Pain / Arthritis}

In the patients, practice has been appeared to have an indispensable job in advancing joint wellbeing without intensifying infection. Patients experiencing joint inflammation who practice normally have less joint agony, greater imperativeness, better rest, diminished morning joint firmness and improved day by day living capacity. Specifically, yoga consolidates significant components of body mindfulness, for example, coordination, balance and postural arrangement, which are all especially significant in people with joint sickness (American College of Rheumatology, 2017). A far reaching survey of randomized controlled preliminaries that assessed yoga as a mediation for incessant low back agony (CLBP) bolstered the practices and saw them as adequate on momentary upgrades in utilitarian handicap (Holtzman et al., 2013). Actually, yoga treatment has been appeared to improve torment, back capacity, spinal versatility, sorrow and uneasiness in patients with CLBP to a more prominent degree than exercise based recuperation (Holtzman et al., 2013; Tilbrook et al., 2011).

\section{Cardiovascular Diseases}

Cardiovascular ailment (CVD) envelops a wide range of disorder, including atherosclerosis, stroke, arrhythmia, hypertension, hyperlipidemia, coronary 
illness and fringe vascular sickness, and is the main source of mortality, horribleness and inability overall. Yoga treatment might be a noteworthy and financially savvy treatment for CVD by intruding on some of these various occasions along this course (Sarvottam et al., 2013; Chu et al., 2016; Manchanda et al., 2014; Dzau et al., 2006). An investigation done by Sarvottam et al. recommending that even a transient yoga-based program may diminish the hazard for CVD. In this preliminary, a ten-day yoga mediation program was found to essentially decrease the weight files and systolic blood pressures in 51 overweight and corpulent men. These men were additionally found to have huge changes in certain provocative markers with diminishes in IL-6 and height of adiponectin (Sarvottam et al., 2013).

Writing audit detailed huge upgrades in general cardiovascular continuance of youthful subjects who were given changing times of yoga preparing (Raub et al., 2002). Physical wellness expanded when contrasted with different types of activity what's more, longer length of yoga practice delivered better cardiopulmonary perseverance. Actually yoga in heart wellbeing inferred that it tends to be valuable in the essential and optional counteraction of cardiovascular sickness and that it can play an essential or a reciprocal job in such manner (Jayasinghe et al., 2004).

\section{Inflammation}

Inflammation is the body's normal resistant reaction to disease, injury, and stress. Be that as it may, irritation can have genuine wellbeing suggestions when it gets delayed and constant. Constant fundamental irritation may not be as evident as intense aggravation, and can continue undetected at low levels for quite a long time. This can gradually harm the body, lead to the advancement of ceaseless illnesses and increment one's hazard for type II diabetes, atherosclerosis, cardiovascular infection, immune system sickness and age-related ailments.

As recently examined, yoga is useful for diminishing both intense and constant feelings of anxiety. In different investigations, yoga has been found to diminish incendiary markers, for example, C-responsive protein and other fiery cytokines in the blood, while expanding levels of numerous immunoglobulins and common executioner cells (Ross et al., 2010). Ongoing examination has additionally indicated that the individuals who practice yoga normally have more significant levels of leptin and adiponectin in their bodies, both characteristic synthetic concoctions that work to ease irritation in the body. Adiponectin has been seen as a key part of endothelial capacity and is cardio protective (Kiecolt-Glaser et al., 2012).

\section{Mental Health/ Neurotransmitters}

Yoga can upgrade one's otherworldly life and point of view past the genuine life paying little heed to one's specific religion (Nespor et al., 1993). It empowers individuals to accomplish and keep up a harmony among effort and unwinding, and this creates a solid and dynamic condition of homeostatic balance. Ongoing investigations have indicated that yoga improves state of mind and lessens sorrow scores (Lavey et al., 2005; Shapiro et al., 2007). These progressions have been ascribed to an expanded discharge of thalamic GABA with more noteworthy limit with respect to enthusiastic guideline (Shapiro et al., 2007; Streeter et al., 2010). Indeed, even a 10day yogabased way of life alteration program has been accounted for to improve emotional prosperity scores of patients (Sharma et al., 2008). A survey via Carim-Todd et al. (2013) on yoga and smokingend, revealed positive advantages of brain body interventions. These intercessions created changes in smoking conduct/in indicators of smoking conduct, for example, forbearance, diminished number of cigarettes smoked; lower power of desires and attitudinal changes respects smoking. Notwithstanding, positive ends on their advantages for smoking end proved unable be attracted because of the shortage of papers, low nature of certain distributions, and the various constraints of the investigations, for example, decreased example size, 
impediments of study configuration, absence of adherence checking, absence of target measures, deficient or missing control conditions and nonappearance of blinding.

Notwithstanding its advantages for patients themselves, yoga additionally has an extraordinary job for overseeing misery showing in family parental figures of patients with dementia (Waelde et al., 2004). Scientists likewise bolster the promising job of yoga as mediation for gloom since it the intercession is financially savvy and simple to execute (Uebelacker et al., 2010) Anyway a point to consider is that all the mind body intercessions do appear to be compelling when contrasted with aloof controls yet reports are less decisive when contrasted and dynamic controls (Uebelacker et al., 2010).

\section{Telomeres}

Telomeres are little, monotonous, chromosomal arrangements found toward the finish of chromosomes which shield the chromosome from disintegration and cell demise. They keep the chromosome stable. Telomere shortening, or unwinding, influences how rapidly cells age. As they abbreviate, the chromosome's basic respectability debilitates. Telomere length has been seen as a prognostic marker of maturing, ailment and untimely bleakness in people. Shorter telomeres are related with cell maturing, cell demise, untimely maturing and an expansive scope of maturing related sicknesses, including cardiovascular malady, malignant growth, stroke, dementia, heftiness, osteoporosis, Alzheimer's, macular degeneration, AIDS, and osteoarthritis (Epel et al., 2004).

As contemplation, care practices and yoga have been moving increasingly more into the standard, it is turning out to be progressively evident that these practices may work to shield our brains and bodies from shrinking with age by conceivably balancing out, and in any event, extending telomeres.

\section{Respiratory Disorders}

Logical premise of utilizing yoga as an assistant treatment in ceaseless obstructive aspiratory sicknesses is settled with noteworthy upgrades in lung work, personal satisfaction files and bronchial incitement reactions combined with diminished requirement for standard and salvage therapeutic use (Vempati et al., 2009). Behera detailed detectable improvement in dyspnoea and lung work in patients of bronchitis following a month of yoga treatment that utilized an assortment of stances and breathing methods. Yogic cleaning methods, for example, dhautikriya (upper gastrointestinal cleaning with warm saline or muslin material) and netikriya (warm saline nasal wash) evacuate unnecessary mucous emissions, decline irritation and decrease bronchial excessive touchiness in this manner expanding incitement edge while kapalabhati through mighty exhalations improves the ability to breathe out against obstruction. A vague broncho defensive or broncho loosening up impact has been additionally hypothesized while improved exercise resistance has been accounted for following yoga treatment in patients of incessant serious aviation routes hindrance. It has been accounted for that all around performed moderate yogic breathing keeps up better blood oxygenation without expanding minute ventilation, diminishes thoughtful initiation during elevation prompted hypoxia and diminished chemoreflex affectability to hypoxia and hypercapnia (Spicuzza et al., 2000). These assistance achieve both target and abstract enhancements in the state of patients with bronchitis. Yoga as a treatment is additionally financially savvy, generally straightforward and conveys insignificant hazard and consequently ought to be supported as an assistant, corresponding treatment as we continued looking for a coordinated arrangement of medication equipped for creating wellbeing and prosperity for all. 


\section{Metabolic / Endocrine Conditions / Diabetes}

A couple RCTs have proposed that yoga and reflection rehearses follow up on the hypothalamicpituitary-adrenal pivot (HPA) hub to diminish cortisol levels in plasma (West et al., 2004) just as lessen thoughtful sensory system tone, increment vagal action (Riley et al., 2004) and lift mind GABA levels. Major orderly surveys of the impacts of yoga on hazard files related with insulin opposition condition and hazard profiles in grown-ups with type 2 diabetes have been done lately (Innes et al., 2007). They revealed post-mediation improvement in different records however with results shifting by populace and study structure. Another efficient survey tended to the administration of type 2 diabetes and inferred that the investigated preliminaries recommend ideal impacts of yoga on transient parameters identified with diabetes however not really for long haul result (Aljasir et al., 2010). The AHRQ refers to two investigations looking at yoga versus prescription which announced an enormous and critical decrease of fasting glucose in people with type 2 diabetes in one, and a littler yet at the same time noteworthy improvement in the other (Ospina et al., 2007).

\section{Musculoskeletal Conditions}

An audit by Posadzki et al. (2011) found that 10 of 11 RCTs detailed fundamentally more prominent impacts for Yoga when contrasted with standard consideration, self-care, restorative activities, loosening up yoga, contact and control, or no mediation. Yoga was more viable for ceaseless back agony than the control mediations, for example, normal consideration or customary remedial activities however a few examinations demonstrated no between bunch contrasts (Posadzki et al., 2011). As of late two all around structured preliminaries of yoga for back agony detailed clinically significant advantages over normal clinical consideration yet not over a concentrated extending intercession (Tilbrook et al., 2011).

\section{Cancer}

As indicated by the discoveries of a thorough metaanalysis of yoga in malignant growth, yoga bunches demonstrated enhancements in mental wellbeing when contrasted with shortlist or strong treatment bunches (Tsauo et al., 2011). As for by and large personal satisfaction, there was a pattern towards progress. To clarify the positive results, Smith \& Pukall (2009) proposed different complex pathways which may include unwinding, adapting procedures, acknowledgment, and self-viability. Kochupillai et al. (2005) announced increment in normal executioner cells in malignant growth patients who had finished their standard treatment in the wake of rehearsing Sudarshan Kriya Yoga and pranayam breathing procedures. A precise audit and meta-examination of RCTs on the physical and psychosocial advantages of yoga in malignant growth patients and survivors by Buffart and partners reasoned that yoga might be an attainable intercession as gainful impacts on a few physical and psychosocial indications were accounted for (Buffart et al., 2012). They indicated that it has solid valuable consequences for misery, uneasiness and despondency, moderate impacts on weakness, general HRQoL, passionate capacity and social capacity, little impacts on utilitarian prosperity, and no huge impacts on physical capacity and rest unsettling influences. It was proposed that yoga can be a suitable type of activity for malignant growth patients and survivors who can't or reluctant to take an interest in other conventional high-impact or obstruction practice programs.

\section{Pregnancy}

Starter proof from different logical examinations bolsters yoga's potential adequacy, especially whenever began right off the bat in the pregnancy. Ladies rehearsing yoga in their subsequent trimester revealed noteworthy decreases in physical torment from pattern to post mediation contrasted and ladies in the third trimester whose agony expanded (Beddoe et al., 2009). Ladies in their third trimester 
demonstrated more prominent decreases in apparent pressure and attribute tension. Another examination detailed essentially less pregnancy inconveniences at 38-40 long stretches of development (Sun et al., 2009). Subjects who took part in the yoga program showed higher result and self-adequacy hopes during dynamic and second phase of work. Arrangement of booklets and recordings on yoga during pregnancy may add to a decrease in pregnancy distresses and improved labor self-viability. Satyapriya et al. (2009) reasoned that yoga diminishes apparent pressure and improves versatile autonomic reaction to worry in solid pregnant ladies while Chuntharapat et al. (2008) presumed that yoga delivered more significant levels of maternal solace during work and 2 hour postwork with a diminishing in subject assessed work torment. They additionally detailed shorter span of the principal phase of work, just as complete time of work in subjects rehearsing yoga. An examination by Narendran et al. (2005) detailed a lower pattern in the event of confusions of pregnancy, for example, pregnancy-instigated hypertension, intrauterine development impediment and pre-term conveyance in subjects who rehearsed yoga. They inferred that a coordinated way to deal with yoga during pregnancy is sheltered and that it improved birth weight, diminished preterm work, and decreased IUGR either in segregation or related with PIH, with no expanded complexities.

\section{Pediatric Population}

A developing measure of proof is demonstrating that yoga and different care based practices are principal for the present youngsters. Because of different new requests and gauges in the present society, youngsters and teenagers experience pressure and psychological wellness challenges that have not been found in previous eras. In a general public detonating with innovation, kids presently are defied with numerous every day interruptions and allurements, with resultant overstimulation and weights from their companions. There are more weights on families with diminished personal time and calm time brought about by the over booking of exercises, exaggerating profitable time and more prominent strain to succeed scholastically. Ongoing exploration shows that the present age of youthful grown-ups is the most "worried" age, contrasted and their ancestors (Sifferlin et al., 2017). There is steady incitement through innovation, web and web-based social networking, just as broad media use by youngsters and teenagers in this day and age. Not exclusively are youngsters and youthful grown-ups under more pressure, however they likewise have less adapting abilities to deal with these stressors. Likewise with grown-ups, when youngsters disguise pressure, it is frequently showed genuinely, bringing about medical problems, for example, sleep deprivation, constant stomach torment, cerebral pains, gloom, tension and emotional episodes (Yoga for Kids, 2016). For the past number of years, schools have been cutting projects, for example, fundamental abilities courses and physical instruction classes. At the point when these pressures the executives abilities are not educated at an early age, it just gets more enthusiastically to learn them as the kids get more seasoned. Yoga may support kids, youths and youthful grown-ups adapt to worry by showing them self-guideline abilities to control feelings and worry at a youthful age. These practices would, thusly, help their prosperity and psychological wellbeing, improve generally speaking flexibility and help to decidedly keep their lives in balance. Yogic practices help the body to associate with the brain by helping one to concentrate on the current second and freeing the psyche from overpowering considerations. Indeed, even extremely little youngsters can figure out how to profit by yogic breathing procedures, which can assist with quieting and occupy babies from a hissy fit or help them to rest. As per the National Institutes of Health, kids who practice yoga have an expanded feeling of mindfulness and fearlessness. Fixation aptitudes are upgraded (The Benefits of Yoga for Kids, 2016). These educated brain body abilities can likewise enable a youngster to reevaluate a troublesome, or 
even excruciating, experience into one that reinforces their feeling of flexibility (Rosen et al., 2015). This, thus, may add to improved consideration, confidence, strengthening and great psychological wellness (Hagen et al., 2014; Khalsa et al., 2013; 2016).

Yoga has been proposed as a possibility for youngsters to increment physical action and wellness and that yoga might be an entryway for embracing a solid dynamic way of life in inactive kids who are scared by increasingly energetic types of activity. They prescribed that further research is important to distinguish clinical uses of yoga for youngsters and that such research should be directed with thorough system in RCTs with nitty gritty portrayal of conventions and announcing of results.

\section{Virus / Corona Virus Disease (CoViD-19)}

The spread of COVID-19 and the disaster we are on the whole confronting today makes us look for answers and course revisions critically required for the very endurance of people. This has brought up numerous issues on our insight base alongside the chaperon social and individual lifestyles. Insusceptibility of the host is a fundamental imperative to encourage the destruction of contaminations. Upset invulnerable frameworks seen as lymphopenia and raised C-receptive protein levels are perceived to be the trademark includes in seriously influenced instances of COVID-19 disease. While the crown infections $(0.06-0.14 \mu)$ are the greatest among infections so far found $(0.005-0.05 \mu)$, we have a lot greater white platelets (WBCs) $(15 \mu)$ which establish our safeguard framework. Moreover, the quantity of WBCs in a single drop (one $\mathrm{ml}$ ) of blood shifts from 5000 to $7000 / \mathrm{ml}$ adding up to a huge number of WBCs in our body, while the quantity of COVID-19 infections are a lot littler in number. The WBCs fill in as the main line of guard against the attacking infections constraining their spread and ensuing tissue harm. Subsequently, we have an awesome possibility of prevailing upon the infection assault if our invulnerable framework is ordinary and solid. Consequently, the result of this disease could be either an invite aftereffect of a viable invulnerable reaction that battles COVID-19 as saw in recouping patients with gentle side effects or a condition of safe concealment that cripples the framework prompting movement to extreme harm.

Broad work, both at this college and somewhere else, has indicated that orderly exceptional customized asana rehearses, devoted pranayamas, reflection, and mantras could give a wide range invulnerable develop in the body so popular disease could be turned away or potentially its destructiveness decreased. We distributed the adequacy of incorporated yoga (IY) that included asanas, unwinding methods, breathing practices, and contemplation in accomplishing prior $(\mathrm{p}<0.05)$ sputum antagonism in the yoga bunch when contrasted with control bunch as an extra to antituberculosis treatment in sputum-positive instances of pneumonic tuberculosis in a sanatorium in Bangalore (Visweswaraiah et al., 2004). One month of IY in patients experiencing HIV-1 contamination has detailed a huge decrease in their viral burden with an expansion in the quantity of CD4 invulnerable cells and improvement in their mental states (Naoroibam et al., 2016). An examination on sound people doing supernatural reflection demonstrated higher $(\mathrm{p}<0.01)$ blood levels of B-lymphocyte arrangement just as characteristic executioner (NK) cells, when contrasted with nonmeditators (Xiang et al., 2020). Kamei et al., (2001) announced a huge connection between's alpha cerebrum wave enactment in the frontal flap as found in electroencephalogram (showing tranquil mindfulness) and an expansion in NK movement during yoga works on highlighting the connection between a quiet brain and better cell insusceptibility.

\section{Conclusion}

The act of yoga isn't as simple or as snappy as taking prescription, yet mounting proof proposes it merits the exertion and venture. Yoga encourages one to reconnect with oneself. It can assist with revealing why and how one's ailment may have begun, and 
can work with the body to begin the recuperation time frame starting from the earliest stage. The training can assist one with seeing how they might be responding to the world around them, and may assist them with figuring out how to react from an alternate point of view. Relaxing, calming our minds and interacting with our internal identities all help to bring one of them into the current second. This can eventually assist with soothing one from the weights and stressors from the buzzing about of this exceptionally bustling world. Continuous examination into yoga and care based practices keeps on uncovering and reveal medical advantages, supporting its utilization in wellbeing the board.

The entirety of the above examinations and surveys propose various territories where mindbody treatments, for example, yoga might be advantageous, yet more research is required for basically all of them to build up their advantages decisively. This is valid during the time spent bringing any new treatment into the cutting edge human services framework and isn't astonishing when we understand that the best possible examinations on yoga as a helpful methodology are not more established than a couple of decades. At the end we can say that whatever happens will be from yoga.

\section{References}

Aljasir, B., Bryson, M., \& Al-Shehri, B. (2010). Yoga practice for the management of type II diabetes mellitus in adults: A systematic review. Evid Based Complement Alternat Med, 7, 399-408.

Amaranath, B., Nagendra, H.R., \& Deshpande, S. (2016). Effect of integrated yoga module on positive and negative emotions in home guards in Bengaluru: A wait list randomized control trial. Int J Yoga, 9, 35-43.

American College of Rheumatology. (2017). Exercise and Arthritis. Available online: http://www.rheumatology.org/I-Am-A/PatientCaregiver/Diseases-Conditions/Living-Well-withRheumatic-Disease/Exercise-and-
Arthritis\#sthash.2dxYmjdw. dpufRA (accessed on 30 January).

Basavaraddi, I.V. (2015). Yoga: Its origin, history and development. $\quad$ Retrieved from https://www.mea.gov.in/in-focusarticle.htm?25096/Yoga.

Beddoe, A.E., Yang, C.P., Kennedy, H.P., Weiss, S.J., \& Lee, K.A. (2009). The effects of mindfulness-based Yoga during pregnancy on maternal psychological and physical distress. J Obstet Gynecol Neonatal Nurs, 38, 310-319.

Bhagwat, S.A. (2008). Yoga and sustainability. Journal of Yoga, 7(1), 1-14.

Buffart, L.M., van Uffelen, J.G., Riphagen, I., Brug, J., van Mechelen, W., Brown, W.J., \& Chinapaw, M.J. (2012). Physical and psychosocial benefits of yoga in cancer patients and survivors, a systematic review and metaanalysis of randomized controlled trials. BMC Cancer, 12,559 .

Carim-Todd, L., Mitchell, S.H., \& Oken, B.S. (2013). Mindbody practices: an alternative, drug-free treatment for smoking cessation? A systematic review of the literature. Drug Alcohol Depend, 132, 399-410.

Chu, P., Pandya, A., Salomon, J.A., Goldie, S.J., \& Hunink, M.G. (2016). Comparative effectiveness of personalized lifestyle management strategies for cardiovascular disease risk reduction. J Am Heart Assoc, 5, e002737.

Chuntharapat, S., Petpichetchian, W., Hatthakit, U. (2008). Yoga during pregnancy: Effects on maternal comfort, labor pain and birth outcomes. Complement Ther Clin Pract, 14, 105-115.

Danhauer, S.C., Addington, E.L., Sohl, S.J., Chaoul, A. \& Cohen, L. (2017). Review of yoga therapy during cancer treatment. Support Care Cancer, 25(4), 1357-1372.

Davidson, R., \& Lutz, A. (2008). Buddha's brain: Neuroplasticity and meditation. IEEE Signal Process Mag, 25, 176-174.

Davidson, R., Kabat-Zinn, J., Schumacher, J., Rosenkranz, M., Muller, D., Santorelli, S., Urbanowski, F., Harrington, A., Bonus, K., \& Sheridan, J. (2003). Alterations in brain and immune function produced by mindfulness meditation. Psychosom Med, 65, 564-570.

DeBruin, E., Formsma, A.R., Frijstein, G., \& Bogels, S.M. (2017). Mindful2Work: Effects of combined physical 
exercise, yoga and mindfulness meditations for stress relieve in employees. A proof of concept study. Mindfulness, 8, 204-217.

Deepeshwar, S., Vinchurkar, S.A., Visweswaraiah, N.K., \& Nagendra, H.R. (2015). Hemodynamic responses on prefrontal cortex related to meditation and attentional task. Front Syst Neurosci, 8, 252.

Dhand, A. (2002). The dharma of ethics, the ethics of dharma: Quizzing the ideals of Hinduism. Journal of Religious Ethics, 30(3), 347-372.

Dzau, V.J., Antman, E.M., Black, H.R., Manson, J.E., Plutzky, J., Popma, J.J., \& Stevenson, W. (2006). The cardiovascular disease continuum validated: Clinical evidence of improved patient outcomes: Part 1: Pathophysiology and clinical trial evidence (risk factors through stable coronary artery disease). Circulation, 114, 2850-2870.

Epel, E.S., Blackburn, E.H., Lin, J., Dhabhar, F.S., Adler, N.E., Morrow, J.D., Cawthon, R.M. (2004). Accelerated telomere shortening in response to life stress. Proc Natl Acad Sci, 101, 17312-17315.

Gulati, M.N. (2008). Comparative religions and philosophies: Anthropomorphism and divinity. New Delhi, India: Atlantic Publishers and Distributors, 168.

Hagen, I., \& Naya, U.S. (2014). Yoga for children and young people's mental health and well-being: Research review and reflections on the mental health potentials of yoga. Front Psychiatry, 5, 35.

Hernández, S.E., Suero, J., Barros, A., González-Mora, J.L., \& Rubia, K. (2016). Increased grey matter associated with long-term sahaja yoga meditation: A voxel-based morphometry study. PLoS ONE, 11, e0150757.

Holtzman, S., \& Beggs, R.T. (2013). Yoga for chronic low back pain: A meta-analysis of randomized controlled trials. Pain Res Manag, 18, 267-272.

Hunter, D.J., \& Reddy, K.S. (2013). Noncommunicable diseases. NEJM, 369, 1336-1343.

Immunity [Internet]. (2013) [updated 2013 Nov 4; cited 2013 Nov 5]. Available from: http://en.wikipedia.org/wiki/Immunity_\%28medical\% 29

Innes, K.E., \& Vincent, H.K. (2007). The influence of yogabased programs on risk profiles in adults with type 2 diabetes mellitus: A systematic review. Evidence-Based Complementary and Alternative Medicine, 4, 469-486.

Jayasinghe, S.R. (2004). Yoga in cardiac health (a review). European Journal of Cardiovascular Prevention and Rehabilitation, 11, 369-375.

Jyotsna, VP. (2014). Prediabetes and type 2 diabetes mellitus: Evidence for effect of yoga. Indian J Endocr Metab, 18, 745-749.

Kaelber, W.O. (1976). "Tapas", birth, and spiritual rebirth in the Veda. History of Religions, 15(4), 343-386.

Kamei, T., Toriumi, Y., Kimura, H., \& Kimura, K. (2001). Correlation between alpha rhythms and natural killer cell activity during yogic respiratory exercise. Stress Health, 17, 141-145.

Khalsa, S.B., \& Butzer, B. (2016). Yoga in school settings: A research review. Ann N Y Acad Sci, 1373, 45-55.

Khalsa, S.B., Cohen, L., McCall, T., \& Telles, S. (2016). Principles and practices of yoga in health care. 1st ed., Scotland, UK: Handspring Publishing.

Khalsa, S.B.S. (2013). Yoga in schools research: Improving mental and emotional health. In Proceedings of the Second International Conference on Yoga for Health and Social Transformation (7-10 January 2013), Haridwar, India.

Kiecolt-Glaser, J.K., Christian, L.M., Andridge, R., Hwang, B.S., Malarkey, W.B., Belury, M.A., Emery, C.F., \& Glaser, R. (2012). Adiponectin, leptin, and yoga practice. Physiol Behav, 107, 809-813.

Klainin-Yobas, P., Oo, W.N., Yew, P.Y.S., \& Lau, Y. (2015). Effects of relaxation interventions on depression and anxiety among older adults: A systematic review. Aging Ment Health, 19, 1043-1055.

Kochupillai, V., Kumar, P., \& Singh, D. (2005). Effect of rhythmic breathing (SudarshanKriya and Pranayam) on immune functions and tobacco addiction. Ann N Y Acad Sci, 1056, 242-252.

Lavey, R., Sherman, T., \& Mueser, K.T. (2005). The effects of yoga on mood in psychiatric inpatients. Psychiatr Rehabil J, 28, 399-402.

Lochtefeld, J.G. (2003). The illustrated encyclopedia of Hinduism. Vol. 2: N-Z, Rosen Publishing, 777. 
Manchanda, S.C. (2014). Yoga-A promising technique to control cardiovascular disease. Indian Heat Assoc, 66, 487-489.

Mehrotra, S., Salunkhe, U., \& Chakraborty, I. (2017). Patanjali: An Indian FMCG on growth path. Emerald Emerging Markets Case Studies, 7(2), 1-35.

Miller, J.J., Fletcher, K., Kabat-Zinn, J. (1995). Three-year follow-up and clinical implications of a mindfulness meditation-based stress reduction intervention in the treatment of anxiety disorders. Gen Hosp Psychiatry, 17, 192-200.

Naoroibam, R., Metri, K.G., Bhargav, H., Nagaratna, R., \& Nagendra, H.R. (2016). Effect of integrated yoga (IY) on psychological states and CD4 counts of HIV-1 infected patients: A randomized controlled pilot study. Int $J$ Yoga, 9, 57-61.

Narendran, S., Nagarathna, R., Narendran, V., Gunasheela, S., \& Nagendra, H.R.R. (2005). Efficacy of yoga on pregnancy outcome. J Altern Complement Med, 11(2), 237-244.

Nespor K. (1993). Twelve years of experience with Yoga in psychiatry. Int J Psychosom, 40, 105-107.

Ospina, M.B., Bond, K., \& Karkhaneh, M. (2007). Meditation practices for health: State of the research. Evid Rep Technol Assess, 155, 1-263.

Posadzki, P., \& Ernst, E. (2011). Yoga for low back pain: a systematic review of randomized clinical trials. Clin Rheumatol, 30, 1257-1262.

Posadzki, P., Ernst, E., Terry, R., \& Lee, M.S. (2011). Is yoga effective for pain? A systematic review of randomized clinical trials. Complement Ther Med, 19, 281-287.

Raub, J.A. (2002). Psychophysiologic effects of Hatha yoga on musculoskeletal and cardiopulmonary function: A literature review. Journal of Alternative and Complementary Medicine, 8, 797-812.

Ricard, M., Lutz, A., \& Davidson, R. (2014). Mind of the meditator. Sci Am, 311, 38-45.

Riley, D. (2004). Hatha yoga and the treatment of illness. AlternTher Health Med, 10, 20-21.

Rosen, L., French, A., \& Sullivan, G. (2015). Complementary, holistic, and integrative. Pediatr Rev, 36,468 .
Ross, A., \& Thomas, S. (2010). The health benefits of yoga and exercise: A review of comparison studies. J Altern Complement Med, 16, 3-12.

Sarvottam, K., Magan, D., Yadav, R.K., Mehta, N., \& Mahapatra, S.C. (2013). Adiponectin, interleukin-6, and cardiovascular disease risk factors are modified by a short-term yoga-based lifestyle intervention in overweight and obese men. J Altern Complement Med, $19,397-402$.

Satyaprabha, T.N., Murthy, H., \& Murthy, B.T.C. (2001). Efficacy of naturopathy and Yoga in bronchial asthma - a self-controlled matched scientific study. IJPP , 45, 8086.

Satyapriya, M., Nagendra, H.R., Nagarathna, R., \& Padmalatha, V. (2009). Effect of integrated Yoga on stress and heart rate variability in pregnant women. Int J Gynaecol Obstet, 104, 218-222.

Shapiro, D., Cook, I.A., Davydov, D.M. (2007). Yoga as a complementary treatment of depression: Effects of traits and moods on treatment outcome. Evid Based Complement Alternat Med, 4, 493-502.

Sharma, R., Gupta, N., \& Bijlani, R.L. (2008). Effect of yoga based lifestyle intervention on subjective well-being. Indian J Physiol Pharmacol, 52, 123-131.

Sharma, U., \& Sharma, S.K. (1996). Indian political thought. New Delhi, India: Atlantic Publishers, 19.

Sifferlin, A. (2017). The most stressed-out generation? Young Adults (2013). Available online: http://healthland. time.com/2013/02/07/the-moststressed-out-generation-young-adults/.

Smith, K.B., \& Pukall, C.F. (2009). An evidence-based review of yoga as a complementary intervention for patients with cancer. Psycho Oncology, 18, 465-475.

Spicuzza, L., Gabutti, A., Porta, C., Montano, N., \& Bernardi, L. (2000). Yoga and chemoreflex response to hypoxia and hypercapnia. Lancet, 356, 1495-1496.

Streeter, C.C., Whitfield, T.H., \& Owen, L. (2010). Effects of yoga versus walking on mood, anxiety, and brain GABA levels: A randomized controlled MRS study. J Altern Complement Med, 16, 1145-1152.

Sun, Y.C., Hung, Y.C., Chang, Y., \& Kuo, S.C. (2009). Effects of a prenatal yoga programme on the discomforts of pregnancy and maternal childbirth selfefficacy in Taiwan. Midwifery, 2, 24. 
Tekur, P., Nagarathna, R., Chametcha, S., Hankey, A., \& Nagendra, H.R. (2012). A comprehensive yoga programs improves pain, anxiety and depression in chronic low back pain patients more than exercise: An RCT. Complement Ther Med, 20, 107-118.

The Benefits of Yoga for Kids. (2016) One Downward Dog at a Time. Available online: http://www.good2grow.com/healthy-livinglibrary/the-benefits-of-yoga-for-kids-one-downwarddog-at-a-time\#sthash.2nc91QVF.dpuf.

Tilbrook, H.E., Cox, H., \& Hewitt, C.E. (2011). Yoga for chronic low back pain: a randomized trial. Annals of Internal Medicine, 155, 569-578.

Tilbrook, H.E., Cox, H., Hewitt, C.E., Kang'ombe, A.R., Chuang, L.H., Jayakody, S., Aplin, J.D., Semlyen, A., Trewhela, A., Watt, I., \& Torgerson D.J. (2011). Yoga for chronic low back pain: A randomized trial. Ann Intern Med, 155, 569-578.

Tsauo, J.Y., Lin, K.Y., Hu, Y.T., Chang, K.J., \& Lin, H.F. (2011). Effects of yoga on psychological health, quality of life, and physical health of patients with cancer: A meta-analysis. Evidence-Based Complementary and Alternative Medicine, 2011, 659876.

Tummers, N. (2009). Teaching yoga for life. First edition, Champaign, IL: Human Kinetics, Inc., 16-17.

Uebelacker, L.A., Epstein-Lubow, G., \& Gaudiano, B.A. (2010). Hatha yoga for depression: critical review of the evidence for efficacy, plausible mechanisms of action, and directions for future research. J PsychiatrPract, 16, 22-33.

Vempati, R., Bijlani, R.L., \& Deepak, K.K. (2009). The efficacy of a comprehensive lifestyle modification programme based on yoga in the management of bronchial asthma: A randomized controlled trial. BMC Pulm Med, 9, 37.

Villemure, C., Ceko, M., Cotton, V.A., \& Bushnell, M.C. (2015). Neuroprotective effects of yoga practice: Age-, experience-, and frequency-dependent plasticity. Front Hum Neurosci, 9, 281.

Visweswaraiah, N.K., \& Telles, S. (2004), Randomized trial of yoga as a complementary therapy for pulmonary tuberculosis. Respirology, 9, 96-101.

Waelde, L.C., Thompson, L., \&Gallagher-Thompson, D. (2004). A pilot study of a Yoga and meditation intervention for dementia caregiver stress. J ClinPsychol, 60, 677-687.

West, J., Otte, C., Geher, K., Johnson, J., \& Mohr, D.C. (2004). Effects of hatha yoga and African dance on perceived stress, affect, and salivary cortisol. Ann Behav Med, 28, 114-118.

Xiang, Y.T., Yang, Y., Li, W., Zhang, L., Zhang, Q., \& Cheung, T. (2020). Timely mental health care for the 2019 novel coronavirus outbreak is urgently needed. Lancet Psychiatry; 7, 228-229.

Yadav, R.K., Sarvottam, K., Magan, D., Yadav, R. (2015). A two-year follow-up case of chronic fatigue syndrome: substantial improvement in personality following a yoga-based lifestyle intervention. Altern Complement Med, 21, 246-249.

Yoga for Kids: How to Calm Little Minds. Available online:

http://www.todaysparent.com/family/familyhealth/yo ga-for-kids-how-to-calm-little-minds/ (accessed on 21 December 2016). 